\title{
Multiple regression analysis for adoption studies of potato growers in Jammu division
}

\author{
Quadri Javeed Ahmad Peer ${ }^{*}$, M. A. Dar ${ }^{2}$, H. A. Malik ${ }^{3}$ and Jasvinder Kaur \\ ${ }^{1}$ Department of Extension Education, FOA, Wadura, SKUAST-Kashmir (J\&K), INDIA \\ ${ }^{2}$ Division of Extension Education \& Communication, SKUAST-Kashmir(J\&K), INDIA \\ ${ }^{3}$ Directorate of Extension Education, SKUAST-Kashmir(J\&K), INDIA \\ ${ }^{4}$ Department of Extension Education, CCS Haryana Agricultural University, Hisar (Haryana), INDIA \\ *Corresponding author e-mail: qadrijavid2008@gmail.com
}

Received: July 26, 2014; Revised received: October 03, 2014; Accepted: November 19, 2014

\begin{abstract}
The research identified the significant and negative relationship between socio-economic parameters with the level of adoption of recommended crop production technologies reveals that such information could be useful to Department of agriculture, and concerned SAU who strive to maximize production and productivity levels of potato crop. They have to gear-up there extension wings for imparting correct and scientific knowledge of crop production. It also suggested to State Govt. officials to ensure adequate facilities for fertilizers to reap full benefits of this cash crop. The study on determining the correlation between socio-economic standards of potato growers with the level of adoption of the recommended crop production technologies was conducted in sub-tropical zone of Jammu division. Three districts namely Jammu, Kathua and Samba were selected purposively on the basis of maximum area under potato crop. Sample size of 225 potato growers was selected randomly from 15 villages from selected districts and their socio-economic standards were correlated with the level of adoption of crop production technologies as recommended by SKUAST-JAMMU, the concerned SAU. The study revealed that age, education, operational land holding, net income, mass media exposure and extension contact had significant correlation at $p \leq$ 0.05 level of probability with the level of adoption. Studies revealed that $45.78 \%$ of respondents adopted recommended seed rate per hectare, whereas $57.33 \%, 40.89 \%$ and $8.89 \%$ respondents adopted recommended application of nitrogen, phosphorus and potassium to the crop. The study further highlighted highest adoption level for insecticide like dimethoate $30 \mathrm{EC}(52.05 \%)$ and fungicide like metalxyl +mancozeb (57.38\%) respectively.
\end{abstract}

Keywords: Crop production technologies, Level of adoption, Multiple regression, Socio-economic standards

\section{INTRODUCTION}

Potato (Solanum tuberosum Linn.) ranks fourth among the major food crops of the world. It is the staple food of almost half of the world's population .The global area under potato during 2009 was about 18.28 million ha, with a total production of 343.91 million t. India ranks $3^{\text {rd }}$ in area (1.86 million ha) $2^{\text {nd }}$ in production (42.34 million $\mathrm{t}$ ) in the world (Saxena and Mathur, 2013). The production and productivity of the crop have been improved by a number of technological interventions viz., improved varieties, quality and quantity of fertilizers (Kumar and Trehan, 2012; Singh and Lal, 2012; Verma et al,. 2013), irrigation schedule (Bisht et al., 2012), seed size, seed rate, planting distance and pest management. In Jammu division, it occupies highest area cover after rice, wheat and maize and has 16 per cent share in area and 18 per cent share in production under vegetables (Anonymous, 2010). During last five years, there has been 10 per cent increase in area from 4845 hectares in 2002-2003 to 5650 hectares in 2008-2009. Similarly the production has shot up by nine per cent during the same period from 75485 MT to 89600 MT with overall average productivity of potatoes is 15.3-16.0 $\mathrm{MT} / \mathrm{ha}$. It has also been observed that the growers are not adopting recommended practices and consequently not realizing the potential yield of potato crop. Keeping several socio economic parameters under consideration, the study was conducted to understand the problems of growers in the adoption of recommended crop production technology, researchers as well as extension should come out with some concrete findings and suggestions, which can solve these problems. Therefore, it is very essential that the growers are aware about recommended crop production technologies for increasing the vegetable production. The level of adoption of any innovation will be high only if the growers are fully motivated to adopt the new innovations. For this purpose one has to identify the gap between the recommended crop production technology and actual adoption by the growers. So that appropriate emphasis is given by the extension workers to educate the growers to get full 
potential yield of potato crop. Various research studies have established that a number of factors are responsible for causing variation for the adoption of recommended horticultural/ agricultural practices, which are needed to be investigated. In Jammu division potato is a leading cash crop and its production has direct correlation with the socio economic status of farmers (Anonymous 2010). Keeping several socio economic parameters under consideration, the study was conducted to study the level of adoption of recommended practices of potato growers and to study the multiple regression analysis of selected independent variables with the level of adoption of crop production technologies recommended by the concerned SAU-Sher-E-Kashmir University of Agricultural Sciences and Technology of Jammu.

\section{MATERIALS AND METHODS}

The present investigation was carried out in the sub-tropical zone of the Jammu division. Three districts namely Jammu, Kathua and Samba were selected purposively on the basis of maximum area under potato crop. Marh and R S Pura sub-divisions of Jammu district, Dayalachak sub-divisions of Kathua district and Samba sub-division of Samba district were selected purposively for having maximum area under potato crop. Seven villages from sub-division Marh, four villages from sub-division $\mathrm{R} S$ Pura, three villages from sub-division Dayalachak and one village from sub-division Samba were selected purposively on the basis of proportionality of area under potato cultivation. The villages with highest area under potato crop in each of the three sub-divisions were selected for the present study. After the selection of villages, from each village, 15 respondents were selected randomly, making a total sample size of 225 from 15 villages

For collecting reliable information regarding socio-economic profile and adoption of recommended crop production technologies by the potato growers, the structured interview schedule was devised as the appropriate tool. The pre-testing of schedule was done on 15 potato growers of village Dub- Karamdin of Marh sub- division of Jammu district to find out the weaknesses in the any part of the schedule. These 15 respondents were not included in the final sample of 225 respondents. On the basis of information obtained through pre-testing, necessary modification were made in the interview schedule to make it easy for recording the data and to remove ambiguity after consultation with the members of advisory committee. The respondents were interviewed either at their home or at their farms, and their responses were recorded on the spot and data were collected. To assess the extent of adoption of

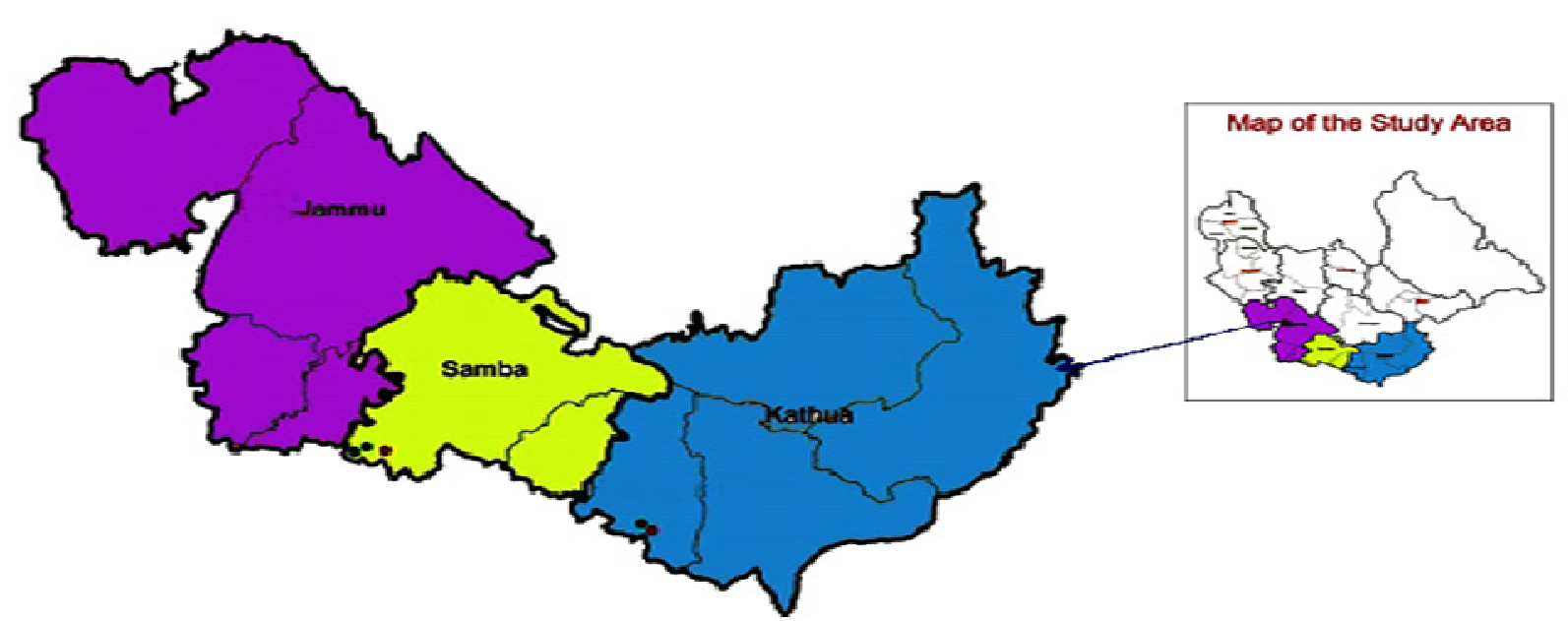

Districts Sub Divisions
Jammu - Marh\&R.S.Pura
-Kathua- Dayalachak
Samba- Samba

1.Pinjore
2.Dabsudan
3. Kalyanpur
4. Gajansoo
5. Dubditta
6. Kanachak
7. Ganguchak
8. Makhanpur

Villages

9.Arnia

Samba- Samba

$\left.\begin{array}{c}\text { Villages } \\ \text { 9.Arnia } \\ \text { 10.Mohanpur } \\ \text { Marh 11.Salahav }\end{array}\right]$

R.S.Pura

Dayala Chak

Samba

Fig. 1. Map of the study area showing Jammu division at $J \& K$. 
recommended crop production technologies, only those practices were studied which were divisible and measured in terms of percentage of the recommended quantities of inputs viz. dosages of FYM, fertilizers, insecticide, fungicide and seed rate etc. Level was measured on the basis of its deviations from the recommended package and practice of potato crop developed by SKUAST-Jammu with the help of multiple regression equation.

The results are presented as per three levels of adoption viz. less than recommended, as per recommendation and more than recommendation. The data were analyzed using descriptive survey design of research.

\section{RESULTS AND DISCUSSION}

It is evident from the figures presented in Table 1 that out of total 10 selected independent variables of potato growers' like age, education, operational land holding, net income from potato crop, mass media exposure and extension contact had significant contribution with the level of adoption of recommended crop production technologies. The other variables of potato growers viz the type of family, size of family, area under potato crop and social participation had no significant contribution with the level of adoption. The $\mathrm{R}^{2}$ value was 0.939 that revealed that $93.9 \%$ variation in the level of adoption of recommended crop technologies of potato growers. Multiple regression analysis showed significant contribution of age with level of adoption of recommended crop production technologies by 4.17 units. These findings are in conformity with the findings of (Singh et al., 2010) for potato growers in potato crop of Ghaziabad (Uttar Pradesh) who had reported that age had significant but negative relationship with adoption of innovation whereas for one unit change in education score resulted in a corresponding increase in the level of adoption by 4.04 units. These findings are in agreement with those of (Prajapati and Patel, 2000 ; Prakash, 2007 ; Singh et al., 2010) for potato growers in Vijapur taluka of Mehsana district in Gujarat, two districts of U.P, Kannauj and Etawah and Ghaziabad (Uttar Pradesh) who had reported that education had positive and significant relation with adoption of innovation. Type of family did not show any significant contribution to the level of adoption of recommended crop production technologies. The findings of the study are in line with the findings (Sharma, 2009) for vegetable crops of Punjab who had reported that type of family had positive and non significant relation with adoption of innovation. Positive and significant relationship with adoption of innovation was recorded for operational land holding where one unit change brought about an increase of 4.7 units in the level of adoption. These findings are in agreement with those of (Patel et al.,2003) for wheat production and (Prakash, 2007) for potato production in two districts of U.P, Kannauj and Etawah who reported that operational land holding had positive and significant relationship with adoption of innovation. Area under crop and social participation however showed non-significant contribution to the level of adoption of recommended crop production technologies. The results were supported by (Sharma, 2009) for vegetable crops of Punjab who had reported that area under crops had non-significant relation with adoption of innovation. Similar findings were reported by (Hakim, 1998) for muskmelon growers of Punjab that there was positive and non-significant relationship between area under muskmelon and level of adoption of recommended cultivation practices. The multiple regression analysis showed that one unit increase in net income would result an increase in the level of adoption of recommended crop production technologies by 2.29 units. These findings are in conformity with (Prajapati and Patel, 2000) for potato growers in Vijapur taluka of Mehsana district in Gujarat (Prakash, 2007), for potato growers in two districts of U.P, Kannauj and Etawah and Singh et al., (2010) for potato growers of Ghaziabad (Uttar Pradesh) who had reported that net income from crops had positive and significant relation with adoption of innovation. Mass media exposure and extension contact showed significant contribution to level of adoption of recommended crop production technologies. These findings are in conformity with (Goudappa et al., 2008) for ground nut growing farmers in Gulbara District of Karnataka and (Kumari,

Table 1. Multiple regression analysis of selected independent variables with the level of adoption.

\begin{tabular}{llll}
\hline Independent variable & \multicolumn{3}{c}{ Coefficients of multiple regression } \\
\hline Age & 'b'value & S.E & $\boldsymbol{t}^{\prime} \boldsymbol{v}$ alue \\
Education & 0.115 & 0.053 & $4.17^{*}$ \\
Type of family & 0.035 & 0.033 & $4.40^{*}$ \\
Size of family & -0.005 & 0.070 & 0.06 \\
Operational land holding & -0.669 & 0.365 & 1.8 \\
Area under potato crop & 2.109 & 0.445 & $4.7^{*}$ \\
Net income from potato crop & -0.304 & 0.257 & 1.1 \\
Social participation & 2.593 & 0.000 & $2.29^{*}$ \\
Mass media exposure & 0.101 & 0.086 & 1.28 \\
Extension contact & 0.007 & 0.093 & $2.75^{*}$ \\
\hline
\end{tabular}

**Significant $p \leq 0.01$ level of probability $\mathrm{R}^{2}=0.939, \mathrm{~F}$ value $=270.124 * * ; *$ Significant $p \leq 0.05$ level of probability 
2010) for rice growing farmers of Jammu Division reported that extension contact had positive and significant relation with adoption of innovation

Level of adoption of recommended seed rate: Only $45.78 \%$ of respondents adopted recommended seed rate, whereas $54.22 \%$ of respondents deviated from recommendation and used less than recommended seed rate. None of the respondents used more than recommended seed rate. Sub-division-wise distribution of respondents showed that $9.52 \%$ respondents from Marh, $45.00 \%$ from R S Pura, $42.22 \%$ from Dayalachak and $33.33 \%$ respondents from Samba subdivision had adopted recommended seed rate. Whereas 50.48, $55.00,57.78$ and $66.67 \%$ of respondents from Marh, R S Pura, Dayalachak and Samba subdivisions, respectively had used less than recommended seed rate (Table 2). The recommended seed rate for three varieties Kufri-Badshah, Kufri-Sindhuri and Kufri-Chipsona mostly used by the potato growers of the Jammu division is 20-25 qt/ha. The adoption of the recommended seed rate as revealed by the study was that more than one-half of the potato growers used less seed rate, probably by following their traditional wisdom to minimize purchase cost on potato seed and ignoring the fact that reduced seed rate lowers production and vis a vis profit. Farmers need to be informed and educated about the benefits of recommended seed rate of potato. The findings are similar to those of (Hakeem, 1998) for muskmelon growers of Punjab (Sharma, 2009) for vegetable crops of Punjab and (Singh et al., 2010) for potato growers in potato crop of Ghaziabad (Uttar Pradesh) who had reported that farmers had used less quantity of seeds for sowing purposes.

Level of adoption of recommended FYM quantity: The data in Table 3 revealed that $32.00 \%$ of respondents used recommended dose of FYM whereas $68.00 \%$ of respondents used less than recommended dose of FYM and none of the respondents had used more FYM than recommendation. The recommended dose of FYM per hectare for Kufri-Badshah, Kufri-Sindhuri and Kufri-Chipsona is 75-100t/ha. Because of not availability, very less percentage of respondents used recommended dose. The findings are in conformity with (Sharma, 2009) for vegetable crops of Punjab and (Kumari, 2010) for rice growing farmers of Jammu Division.

Level of adoption of recommended fertilizer doses: Data in Table 4 showed that $57.33 \%$ of respondents had used recommended dose of urea followed by $26.22 \%$ of respondents who had used less than recommended dose whereas $16.45 \%$ of overall respondents had used more than recommendation. With respect to the level of adoption of Di-Ammonium Phosphate, $40.89 \%$ of total respondents had used recommended dose whereas 7.11 and $52.00 \%$ of respondents had used less and more than recommended doses respectively. Data further revealed that $8.89 \%$ of total respondents used recommended dose of Murate of Potash, whereas $91.11 \%$ of overall respondents used less than recommended dose and none of the respondents had applied more than recommended dose. Subdivision wise distribution of respondents also indicated that majority of the respondents $(66.67 \%)$ from R S Pura had applied urea as per recommendation compared to Marh, Dayalachak

Table 2. Level of adoption of recommended seed rate $(n=225)$.

\begin{tabular}{|c|c|c|c|c|c|}
\hline \multicolumn{3}{|c|}{ Sub-Division-wise percentage of respondents } & \multicolumn{3}{|c|}{ Overall \%age of } \\
\hline Level of adoption & $\begin{array}{l}\text { Marh } \\
(\mathrm{n}=\mathbf{1 0 5})\end{array}$ & $\begin{array}{l}\begin{array}{l}\text { R S Pura } \\
(n=60)\end{array} \\
\text { (n) }\end{array}$ & $\begin{array}{l}\text { Dayalachak } \\
(n=45)\end{array}$ & $\begin{array}{l}\text { Samba } \\
(n=15)\end{array}$ & $\begin{array}{l}\text { Respondents from } \\
\text { all sub divisions }\end{array}$ \\
\hline $\begin{array}{l}\text { Less than } \\
\text { recommendation } \\
\text { As per }\end{array}$ & 50.48 & 55.00 & 57.78 & 66.67 & 54.22 \\
\hline $\begin{array}{l}\text { recommendation } \\
(20-25 \mathrm{q} / \mathrm{ha}) \\
\text { More than }\end{array}$ & 09.52 & 45.00 & 42.22 & 33.33 & 45.78 \\
\hline
\end{tabular}

Table 3. Level of adoption of recommended dose of FYM ( $n=225)$.

\begin{tabular}{llllll}
\hline \multicolumn{2}{l}{ Sub-Division-wise } & percentage of respondents & \multicolumn{2}{c}{ Overall \%age of } \\
\hline Level of adoption & $\begin{array}{l}\text { Marh } \\
(\mathbf{n = 1 0 5})\end{array}$ & $\begin{array}{l}\text { R S Pura } \\
(\mathbf{n = 6 0 )}\end{array}$ & $\begin{array}{l}\text { Dayalachak } \\
(\mathbf{n = 4 5})\end{array}$ & $\begin{array}{l}\text { Samba } \\
(\mathbf{n = 1 5})\end{array}$ & $\begin{array}{l}\text { Respondents from } \\
\text { all sub divisions }\end{array}$ \\
\hline $\begin{array}{l}\text { Less than } \\
\text { Recommendation } \\
\text { As per }\end{array}$ & 64.77 & 65.00 & 68.89 & 100.00 & 68.00 \\
$\begin{array}{l}\text { recommendation } \\
(75-100 q \text { ha) }\end{array}$ & 35.32 & 35.00 & 31.11 & 00.00 & 32.00 \\
$\begin{array}{l}\text { More than } \\
\text { Recommendation }\end{array}$ & 00.00 & 00.00 & 00.00 & 00.00 & 00.00 \\
\hline
\end{tabular}


and Samba, whereas majority of the respondents $(45.00 \%)$ from R S Pura had applied Di-Ammonium Phosphate as per recommended dose as compared to Marh, Dayalachak and Samba respectively. The data further showed that $11.43 \%$ of the respondents from Marh had applied Murate of Potash as per recommended dose as compared to the R S Pura, Dayalachak and Samba subdivisions. Majority of the respondents had not applied recommended doses of fertilizers to the potato crop owing ignorance about the recommended doses of fertilizers i.e.,250-260 kg Urea, 132-140 kg DAP and 192-200 kg MOP. Among the adopters of different fertilizers, majority of the respondents had used recommended doses of urea only. Majority of the respondents had used more than recommended doses of DAP and less than recommended doses of MOP. MOP is not available to the farmers of Jammu divisionon time at sufficient quantities. So efforts have to be made by extension agencies to educate farmers about the correct doses and the state government to ensure adequate quantities of potassic fertilizer to the farmers for maximizing production level of this important crop. The findings are in agreement with (Sharma, 2009) for vegetable crops of Punjab who had reported that less percentage of farmers applied recommended doses of fertilizers to their crops.

Level of adoption of recommended dose of insecticides: Data in Table 5 showed that $44.91 \%$ of respondents adopted recommended dose of Endosulphan
35EC, whereas 34.75 and $20.34 \%$ of respondents used less and more than recommendation. Sub-division wise distribution of respondents indicated that 45.61, 42.42, 42.85, and 57.14\% of respondents from Marh, R S Pura, Dayalachak and Samba had used recommended dose of insecticides respectively, whereas 33.34,38.10 and $42.86 \%$ of respondents from Marh and R S Pura each, Dayalachak and Samba used less than recommendation. 21.05, 24.24 and $19.05 \%$ respondents from Marh, R S Pura and Dayalachak Subdivisions had used more than recommendation. None of the respondents from subdivision Samba had used more than recommended dose of insecticides. For Dimethoate 30EC, $52.05 \%$ respondents had used recommended dose whereas 32.88 and $15.07 \%$ had used less and more than recommended dose. Sub-division-wise distribution depicted that 53.33, 44.44, 47.05 and $75.00 \%$ of respondents from Marh, R S Pura, Dayalachak and Samba had used recommended dose of it. $30.00 \%$ respondents from Marh, 33.33\% from R S Pura, $41.18 \%$ from Dayalachak and $25.00 \%$ from Samba Subdivisions had used less than recommendation. The data further indicated that 16.67, 22.23 and $11.77 \%$ of respondents from Marh, R S Pura and Dayalachak subdivision had used more than recommendation. None of the respondents from subdivision Samba had used more than recommended dose.

Table 4 . Level of adoption of recommended fertilizer doses $\quad(n=225)$.

\begin{tabular}{|c|c|c|c|c|c|}
\hline \multicolumn{3}{|c|}{ Sub-Division-wise percentage of respondents } & \multicolumn{3}{|c|}{ Overall \% age of } \\
\hline Level of adoption & $\begin{array}{l}\text { Marh } \\
(n=105)\end{array}$ & $\begin{array}{l}\text { R S Pura } \\
(n=60)\end{array}$ & $\begin{array}{l}\text { Dayalachak } \\
(n=45)\end{array}$ & $\begin{array}{l}\begin{array}{l}\text { Samba } \\
(n=15)\end{array} \\
\end{array}$ & $\begin{array}{l}\text { Respondents from } \\
\text { all sub divisions }\end{array}$ \\
\hline \multicolumn{6}{|l|}{ Nitrogen(Urea) } \\
\hline $\begin{array}{l}\text { Less than } \\
\text { recommendation }\end{array}$ & 26.67 & 18.33 & 28.89 & 46.67 & 26.22 \\
\hline $\begin{array}{l}\text { As per } \\
\text { recommendation }\end{array}$ & & & & & \\
\hline$(256-260 \mathrm{~kg} / \mathrm{ha})$ & 57.14 & 66.67 & 46.67 & 53.33 & 57.33 \\
\hline More than & & & & & \\
\hline recommendation & 16.19 & 15.00 & 24.44 & 00.00 & 16.45 \\
\hline \multicolumn{6}{|c|}{ Phosphorus (Di-Ammonium Phosphate) } \\
\hline $\begin{array}{l}\text { Less than } \\
\text { recommendation } \\
\text { As per }\end{array}$ & 05.71 & 5.00 & 08.89 & 02.00 & 07.11 \\
\hline $\begin{array}{l}\text { recommendation } \\
\text { (140-142 kg/ha) } \\
\text { More than }\end{array}$ & 40.00 & 45.00 & 42.22 & 26.67 & 40.89 \\
\hline Recommendation & 54.29 & 50.00 & 48.89 & 53.33 & 52.00 \\
\hline \multicolumn{6}{|c|}{ Potassium (Murate of Potash) } \\
\hline $\begin{array}{l}\text { Less than } \\
\text { recommendation } \\
\text { As per }\end{array}$ & 88.57 & 90.00 & 95.56 & 100.00 & 91.11 \\
\hline $\begin{array}{l}\text { recommendation } \\
(190-122 \mathrm{~kg} / \mathrm{ha}) \\
\text { More than }\end{array}$ & 11.43 & 10.00 & 04.44 & 00.00 & 08.89 \\
\hline Recommendation & 00.00 & 00.00 & 00.00 & 00.00 & 00.00 \\
\hline
\end{tabular}


Table 5. Level of adoption of recommended insecticides dose $(n=118)$.

\begin{tabular}{|c|c|c|c|c|c|}
\hline \multicolumn{3}{|c|}{ Sub-Division-wise percentage of respondents } & \multicolumn{3}{|c|}{ Overall \%age of } \\
\hline Level of adoption & $\begin{array}{l}\text { Marh } \\
(n=57)\end{array}$ & $\begin{array}{l}\text { R S Pura } \\
(n=33)\end{array}$ & $\begin{array}{l}\text { Dayalachak } \\
(\mathrm{n}=21)\end{array}$ & $\begin{array}{l}\text { Samba } \\
(n=07)\end{array}$ & $\begin{array}{l}\text { Respondents from } \\
\text { all sub divisions }\end{array}$ \\
\hline \multicolumn{6}{|c|}{ Endosulphon 35EC } \\
\hline \multicolumn{6}{|l|}{ Less than } \\
\hline recommendation & 33.34 & 33.44 & 38.10 & 42.86 & 34.75 \\
\hline \multicolumn{6}{|l|}{ As per } \\
\hline $\begin{array}{l}\text { recommendation } \\
\text { (3 liter/ha) }\end{array}$ & 45.61 & 42.42 & 42.85 & 57.14 & 44.91 \\
\hline \multicolumn{6}{|l|}{ More than } \\
\hline recommendation & 21.05 & 24.24 & 19.05 & 00.00 & 20.34 \\
\hline \multicolumn{4}{|c|}{ Sub-Division-wise percentage of respondents } & \multicolumn{2}{|c|}{ Overall \%age of } \\
\hline Level of adoption & $\begin{array}{l}\text { Marh } \\
(\mathbf{n}=30)\end{array}$ & $\begin{array}{l}\text { R S Pura } \\
(n=18)\end{array}$ & $\begin{array}{l}\text { Dayalachak } \\
(\mathbf{n}=17)\end{array}$ & $\begin{array}{l}\begin{array}{l}\text { Samba } \\
(n=08)\end{array}\end{array}$ & $\begin{array}{l}\text { Respondents from } \\
\text { all sub divisions }\end{array}$ \\
\hline \multicolumn{6}{|l|}{ Dimethoaten=73 } \\
\hline $\begin{array}{l}\text { Less than } \\
\text { recommendation } \\
\text { As per }\end{array}$ & 30.00 & 33.33 & 41.18 & 25.00 & 32.88 \\
\hline $\begin{array}{l}\text { Recommendation } \\
\text { (1liter/ha) } \\
\text { More than }\end{array}$ & 53.33 & 44.44 & 47.05 & 75.00 & 52.05 \\
\hline recommendation & 16.67 & 22.23 & 11.77 & 00.00 & 15.07 \\
\hline
\end{tabular}

Level of adoption of recommended dose of fungicides: Only $48.03 \%$ of respondents had used recommended dose of Copper oxychloride $33.07 \%$ of respondents used less than recommended dose and $18.90 \%$ of respondents used more than recommended dose. Sub-division-wise distribution of respondents depicted that $52.45 \%$ respondents from Marh, $45.71 \%$ respondents from R S Pura, $40.90 \%$ respondents from Dayalachak and 44.45 respondents from Samba had used recommended dose of fungicide, whereas 31.15, $34.29,36.37$, and $33.33 \%$ of respondents from Marh, R S Pura, Dayalachak and Samba subdivisions had used less than recommended dose of fungicides and only $16.40,20.00,22.73$ and $22.22 \%$ of respondents from Marh, R S Pura, Dayalachak and Samba had used more than recommended dose of fungicides.

The study further indicated that $57.38 \%$ of respondents had used recommended dose of Metalxyl+Mancozeb followed by $42.62 \%$ of respondents who had used less than recommended dose, whereas none of the respondents had used more than recommended dose. Sub-division-wise distribution of respondents depicted that $62.97 \%$ respondents from Marh, 56.25\% respondents from $\mathrm{R}$ S Pura, 56.54\% respondents from Dayalachak and $33.34 \%$ respondents from Samba had used recommended dose, whereas $37.03,43.75,41.46$, and $66.66 \%$ of respondents from Marh, R S Pura, Dayalachak and Samba had used less than recommended dose and none of respondents from any of the subdivision had used more than recommended dose.(Table 6)

Level of adoption of recommended dose of insecticides and fungicides: Nearly one-half of the respondents had applied recommended doses of insecticides and fungicides to the potato crop and most of them used it on the advice of neighbours and dealers. Lack of knowledge about the correct doses of insecticides is the single reason and efforts have to be made by extension agencies to educate the farmers. These findings are in conformity with those of (Shivalingaiah and Nagabhushanam, 2004) for potato growers in Belur taluk of Hassan district in Karnataka (Sharma, 2009) for vegetable crops of Punjab and (Singh et al., 2010) for potato growers in potato crop of Ghaziabad (Uttar Pradesh) who had reported that majority of respondents do not follow recommendation regarding insect and disease control.

Majority of the respondents $(81.03 \%)$ had adopted recommended varieties of potato during the month of September. Majority of the respondents purchased seeds from State Department of Agriculture and Private Agencies. It was found that better quality, higher productivity, easy availability and low cost of seeds were the main reasons for procuring the potato seeds every year from State Department of Agriculture and Private Agencies. The data reveals that all of the respondents had used the FYM, urea, DAP and MOP as basal application and all of them had applied urea only as first top dressing. Cutworm, potato aphids and potato leaf hopper were the insect-pests faced by the potato growers in potato crop. Metalaxyl+Mancozeb was used for the control of late blight and early blight diseases in potato crop. Almost one-half of the respondents had used insecticides and fungicides at the time of insect-pests and disease appearance. It was further reported that about half of the respondents of all Sub-divisions did not use proper dose of chemicals because of the main reason that they followed the advice of their neighbourers and the other reasons 
Table 6. Level of adoption of recommended fungicide dose $(n=127+61=181)$.

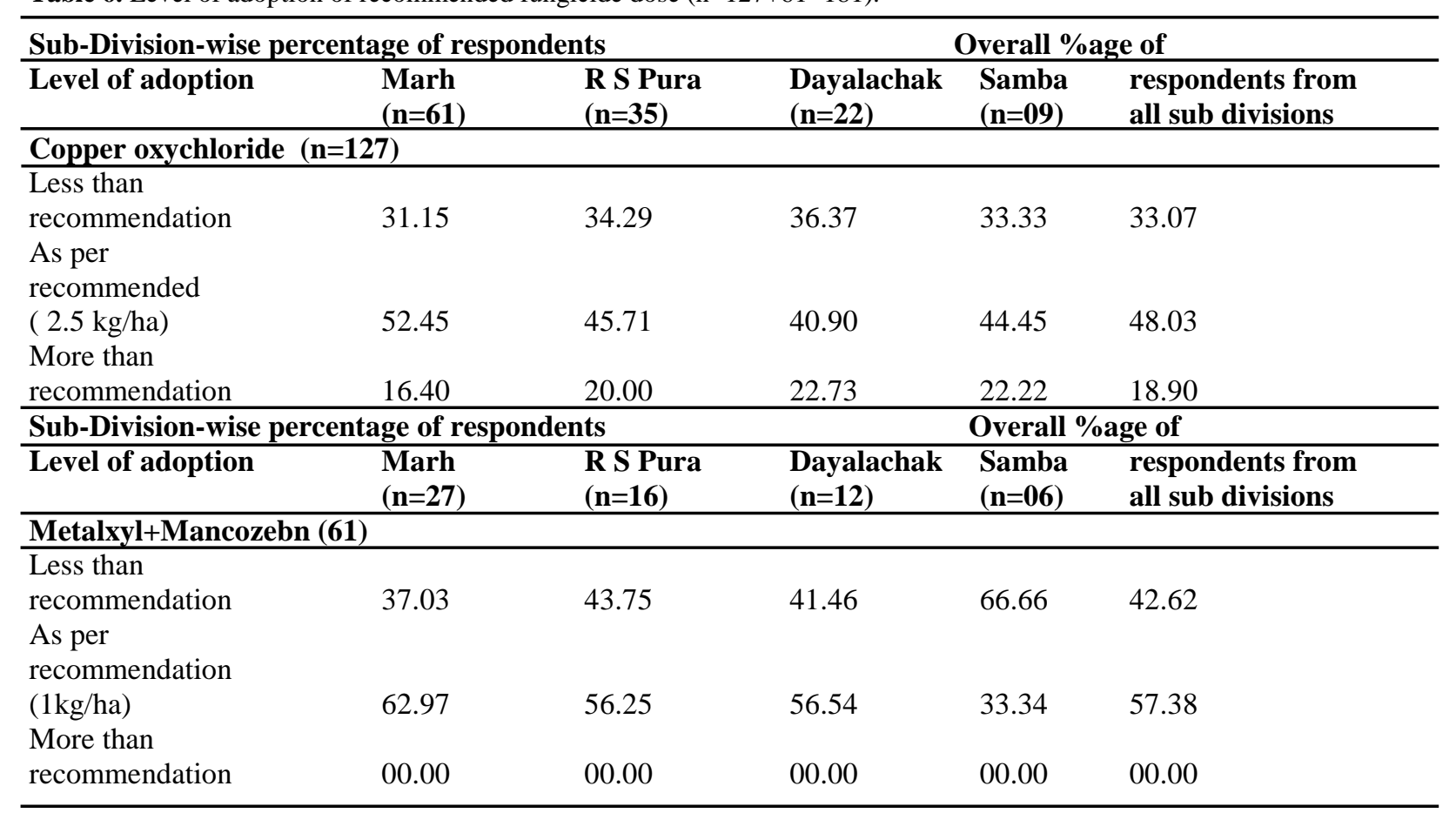

were lack of knowledge and following the advice of dealer.

\section{Conclusion}

The research identified the significant and negative relationship between socio-economic parameters like age, education, operational land holding, net income from potato crop, mass media exposure and extension contact and level of adoption of recommended crop production technologies and negative and non-significant relationship between type of family, size of family, area under potato crop and social participation. Such information could be useful to Department of agriculture, and concerned SAU who strive to maximize production and productivity levels of potato crop. They have to gear-up there extension wings for imparting correct and scientific knowledge of crop production such as level of adoption of any innovation will be high only if the growers are fully motivated to adopt the new innovations, to adopt recommended package of practices, recommended dosage of fertilizers, insecticides and fungicides at proper time. It also suggested to State Govt. officials to ensure adequate facilities for fertilizers to reap full benefits of this cash crop.

\section{ACKNOWLEDGEMENTS}

I extent my sincere thanks to the participating farmers, Department of Agriculture, Jammu and Division of Agricultural Extension Education, Sher-E-Kashmir University of Agricultural Sciences and Technology of Jammu, for their kind support.

\section{REFERENCES}

Anonymous. (2010). A note on command area development
Department of Agriculture, Jammu.

Bisht, P., Raghav, M. and Singh, V.K. (2012).Effect of different irrigation schedule on the growth and yield of drip irrigated potato. Potato. J., 39(2):202-04.

Hakim, A.H. (1998). Adoption of recommended practices for muskmelon cultivation and problems faced by the muskmelon growers of Punjab. PhD thesis at Division of Extension Education, Punjab Agricultural University Ludhiana.

Kumari, G. (2010). Adoption of IPM practices by rice growing farmers of Jammu

Division. PhD thesis at Division of Agricultural Extension Education, Sher-e-Kashmir University of Agricultural Science and Technology of Jammu, Jammu.

Kumar, M. and Trehan, S.P. (2012). Influence of potato cultivars and $\mathrm{N}$ levels on contribution of organic amendments to N nutrition. Potato. J., 39(2):133-44.

Patel, M., Chatterjee, A. and Khan, M. (2003). Adoption of wheat production technology. Indian Journal Extension Education, 9: 58-62.

Prajapati , M.R. and Patel, R.J. (2000). Studied the entrepreneurial behavior of potato growers. Gujarat Journal of Extension Education.10\&11:10-12

Prakash, V. (2007).Adoption extent of potato respondents about potato production technology. International Agriculture Science 3 (1): 223-227(Abstract).

Saxena, R. and Mathur. (2013). Analysis of potato production performance and yield variability in India. Potato. J., 40(1):38-44

Sharma, M. (2009). Adoption of recommended farm practices of major vegetable Crops in Punjab. PhD thesis at Division of Extension Education, Punjab Agricultural University Ludhiana..

Shivalingaiah, Y.N and Nagabhushanam , K. (2000). Perceived training needs of Potato growers, their characteristics and adoption level. Karnataka Journal of Agricultural Science, 17 (2): 264-269.

Singh, B.K., Singh, D.K., Yadav, V.P.S and Singh, L. 
(2010). Adoption behavior of commercial potato growers in District, Ghaziabad (Uttar Pradesh).Indian Research Journal of Extension Education, 10 (3): 5-9.

Singh, S.K. and Lal, S.S. (2012). Effect of potassium nutrition on potato yield, quality and nutrient use efficiency under varied levels of nitrogen application. Potato. J., 39(2):155-65.

Verma, R.B., Kumar, A. and Pathak, S.P. (2013). Studies on nutrient management in potato. Potato. J., 40(1):72-75. 